\title{
Permian Ages of "Younger Granites" from Mounio Province (Gouré area, Southeastern Niger)
}

\author{
Mahamane M. S. Chékaraou and Moussa Konaté
}

\section{ABSTRACT}

The Mounio province, located in Southeastern Niger, consists of PanAfrican formations-intruded by the "Younger Granites" ring complex. In the study area, the "Younger Granites" are represented by volcanic to acid plutonic rocks with hyperalkaline trends (pyroclastic rocks, rhyolites, microgranites, granites, syenites), forming in the North, a circular structure called Gouré ring complex. Preliminary geochronological datings of the Mounio granites have yielded Carboniferous ages. However, recent investigations carried out in this province have identified structures similar to Pan-African deformation structures, such as folds and several generations of schistosity/foliation. Analysis of the relationship between deformation and magmatism has removed any ambiguity regarding the relative age of the deformation. This study focuses on the radiometric dating of the "Younger Granites" of Gouré area, in order to update the geochronological data. Thus, three samples (pyroclastitic rock, rhyolite, microgranite) were dated by the K-Ar method on total rock using a mass spectrometertype MI 1201 IG. Radiometric dating results assign a Lower Permian age (293-287 Ma) to the "Younger Granites" Ring Complex of the Mounio Province in Niger, classically considered to be Carboniferous in age.

Keywords: Mounio Province, Gouré, "Younger Granites", Pan-African mobile belt, Geochronology.

Published Online: December 08, 2021

ISSN: $2684-446 \mathrm{X}$

DOI : $10.24018 /$ ejgeo.2021.2.6.220

M. M. S. Chékaraou*

Abdou Moumouni University of Niamey, Niger.

(e-mail: sandamoustapha@yahoo.fr)

M. Konaté

Abdou Moumouni University of Niamey, Niger.

(e-mail: konate.moussa ${ }^{@}$ gmail.com)

*Corresponding Author

\section{INTRODUCTION}

The Mounio Province, located in southeastern Niger, is an integral part of the Pan-African mobile belt which extends from the Hoggar in the North to the Gulf of Benin in the South, including the Touareg and the Benino-Nigerian Shields (Fig. 1). It consists of Pan-African formations intruded by a ring Complex called "Younger Granites". The latter is classically considered as the ultimate anorogenic manifestations of an intraplate magmatism, in this part of the Trans-Saharan mobile belt. In the study area, granitic complexes are represented by volcanic to acid plutonic rocks with hyperalkaline trends. Several authors have discussed the ages of the anorogenic complexes of the "Younger Granites" Province of Niger-Nigeria, whose emplacement indicates migratory ages from Ordovician to Cretaceous, respectively from the North (Aïr, Niger) to the South (Jos Plateau, Nigeria) (Fig. 2) [1]-[8]. However, very few radiometric datings have been carried out in the Mounio Province, which occupies an intermediate position between the Air complexes (to the North) and those of Nigeria (to the South). The only published studies concern the data on the granites of Kourdohol in west Gouré $(302 \pm 5-296 \pm 5 \mathrm{Ma})$ and Adoumchi in South Mounio ( 295- 289 Ma) obtained by the Rb-Sr method on total rock (Fig. 3), [4], [6]. Most of the ages mentioned have been assigned to Jurassic [9] or
Devono-Carboniferous [10], based on geological correlations. Recent field works have described deformation structures such as folds, sometimes showing high ductility and several slaty cleavages, with various orientations: $\mathrm{N} 00^{\circ}$ $\mathrm{N} 20^{\circ}, \mathrm{N} 110^{\circ}-\mathrm{N} 125^{\circ}$ and $\mathrm{N} 140^{\circ}-\mathrm{N} 160^{\circ}$. It's therefore necessary to verify whether these are Pan-African structures and/or host rocks, as is the case in the North of the study area where metasediments of paleo-neo-proterozoic age are in contact with the annular complex. Additional radiometric data are needed to chronologically calibrate the age of the various deformation structures affecting the Gouré "Younger Granites", in order to remove any ambiguity. The $\mathrm{K}$-Ar dating method on total rock, implemented during this study, allows to update the ages of emplacement of the Mounio "Younger Granites" and the associated deformations. The objective of this study is to determine the radiometric age of the "Younger Granites" of the Goure area. In a specific way, it's to:

- determine the age of the magmatism of the Mounio "Younger Granites",

- chronologically calibrate the age of the deformations with that of the magmatism of the study area,

- place the Mounio province in its regional geological context. 


\section{STUdy AREA}

\section{A. Geological Setting}

The Mounio basement which is a part of the Pan-African mobile zone, located to the East of the West African Craton (WAC), is located in the Southern part of the Trans-Saharan mobile belt which extends from the Hoggar in the North to the Gulf of Benin in the South (Fig. 1). This mobile belt, result of the convergence between four cratons: The West African Craton, the São Francisco Craton, the Congo Craton, and the Saharan Metacraton [11]-[14].

It consists of a Paleo-Neo-Proterozoic basement, deeply remobilized during the Pan-African orogeny (750-450 Ma) [12], [15]-[20]. From a global point of view, the PanAfrican mobile zone is one of the many Neoproterozoic orogenic chains which participated in the accretion of various cratonic blocks, thus forming the Supercontinent of
Gondwana between 750 and 500 Ma. Subsequently, Gondwana began to break up, from the Paleozoic, which led to: (i) the emplacement of anorogenic alkaline granitic complexes commonly called "Younger Granites" and, (ii) the development of Meso-Cenozoic rifts [17], [21], [22]. These anorogenic complexes include the "Younger Granites" Province of Niger-Nigeria. The post-Pan-African magmatism of this province continued until the Quaternary, according to a meridian alignment, associated with a migration from the North to the South [23], [24], [4], [6]. From North to South, these are: the Lower to Middle Paleozoic in age complexes of the Aïr Massif (northern Niger), the Upper Paleozoic in age "Ring Complexes" of the Damagaram-Mounio (southern Niger), and the CretaceousJurassic in age "Younger Granites" of the Jos Plateau (Central Nigeria) [1]-[8], [25].

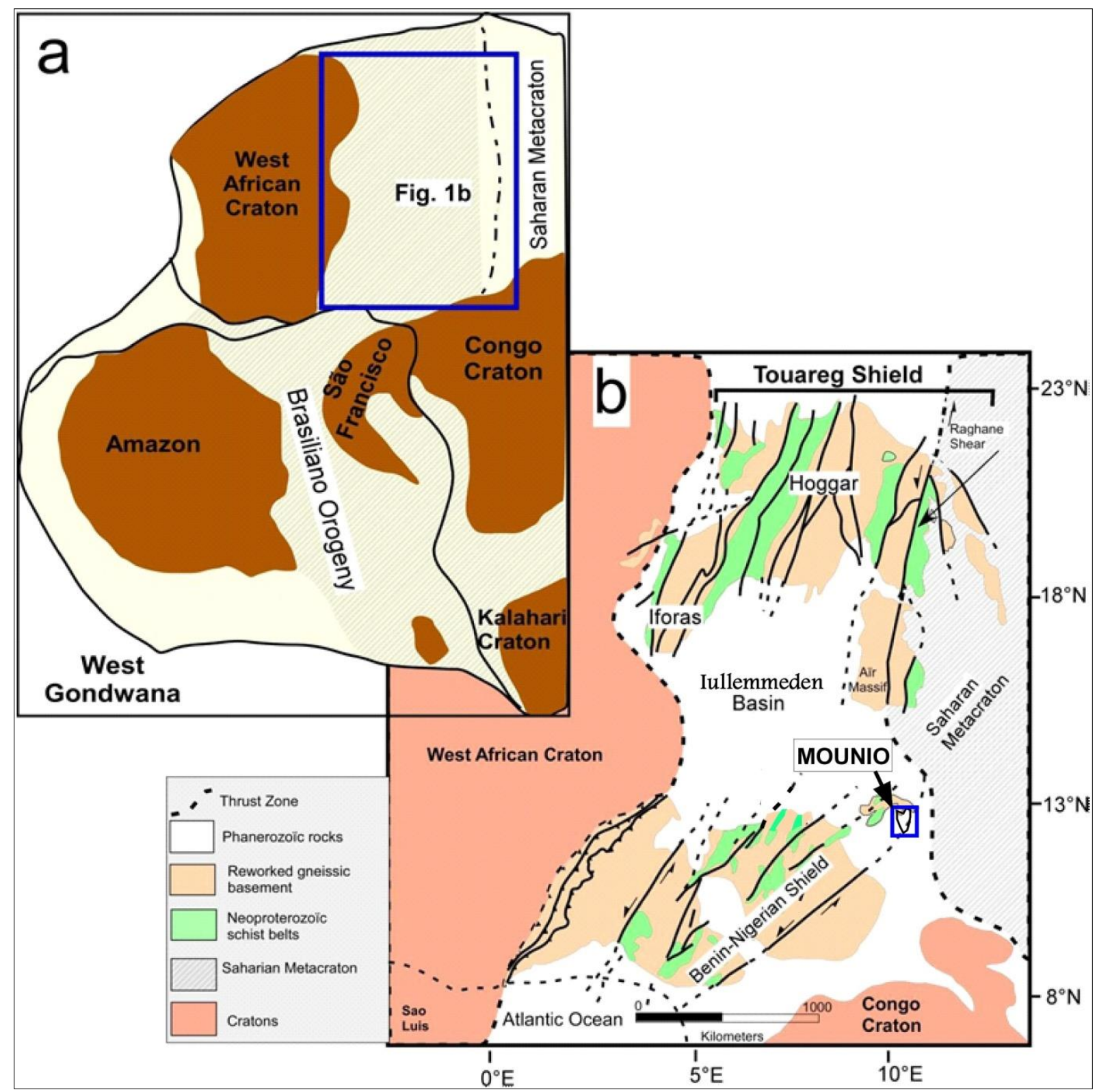

Fig. 1. (a): Reconstitution of the Western part of the Gondwana from the Paleozoic to the Mesozoic, showing the different Cratons. (b): Location of the Mounio province in the Trans-Saharan mobile belt (the blue box outlines the location of the study area) [11], [12], [17], [26]-[33]. 


\section{B. Mounio Province Geology}

The Mounio province extends over $80 \mathrm{~km}$ from North to South of the Gouré city to the nigero-nigerian border and over 30 to $40 \mathrm{~km}$ from East to West (Fig. 3). The geology of this area is dominated by the so-called "Younger Granites" complex which intruded older terrains during two magmatic cycles [34], [35]. The "Younger Granites" form to the North of Gouré city, a circular structure called "Annular Complex of Gouré" (Fig. 3). The first cycle includes rhyolites (with a vitreous, microlithic or porphyritic texture), and rhyolitic pyroclastitic rocks (including breccias, tuffs and ignimbrites). These volcanic rocks were intruded by a hypovolcanic set including microgranites, and then by plutonic bodies including syenites and granites (Fig. 3), representing the second magmatic cycle.

Throughout the Mounio area, the old terranes which are paleo-neo-proterozoic in age [9] are over laid by the sedimentary cover of the Continental Hamadian and the recent aeolian formations [36] except of some metasediment's outcrops (Fig. 3).

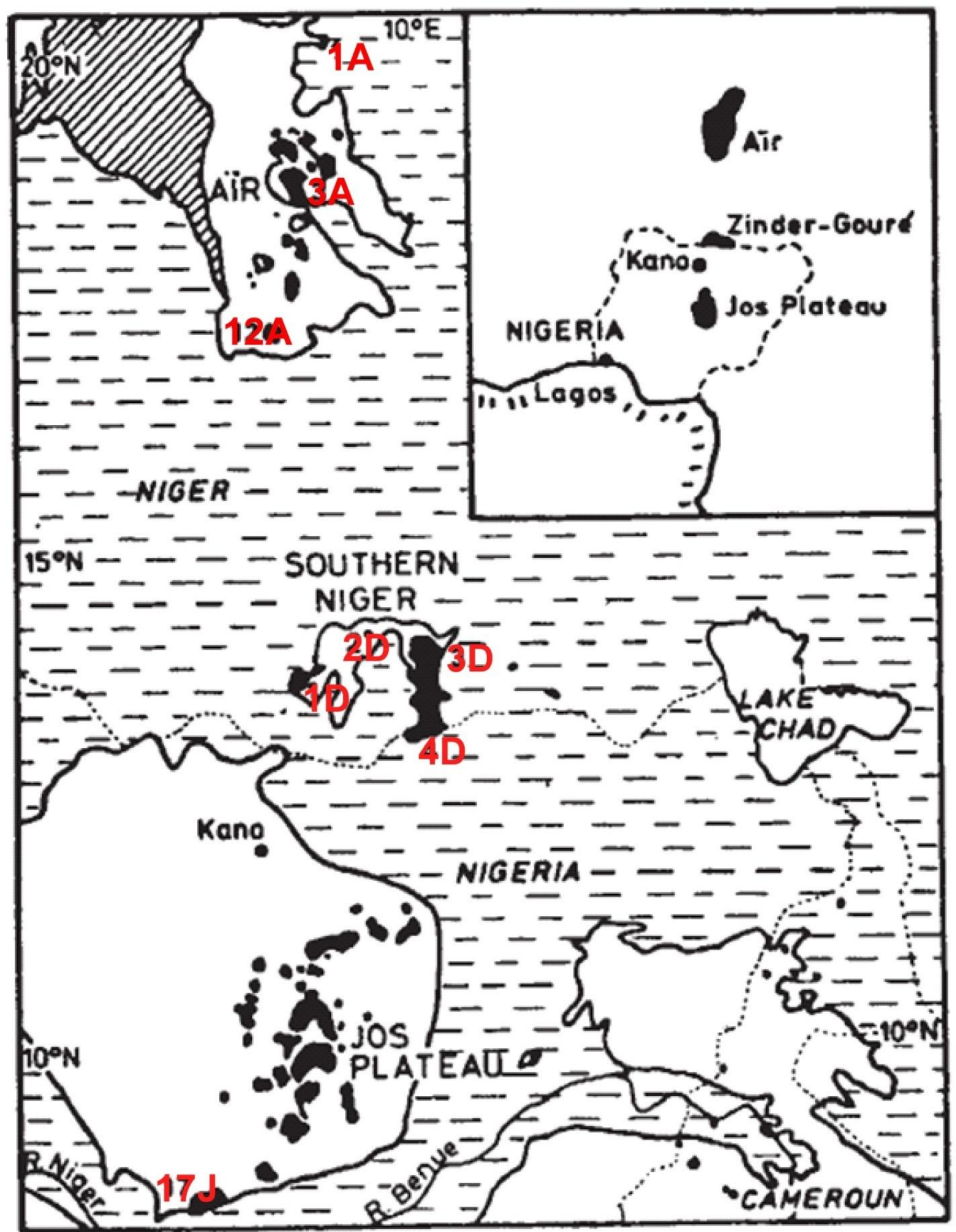

Fig. 2. Distribution of Paleozoic and Mesozoic Ring complexes of Niger and Nigeria. Aïr (Middle Paleozoic): 1A.Adrar Bous, 3A.Tamgak-Enfoud Group, 12.Tarraouadji; Southern Niger (UpperPaleozoic): 1D.Zinder, 2D.Tchouni-Zarniski, 3D.Gouré, 4D.Matsena; Nigeria (Mesozoic): Jos Tray, 17J.Afu. [6]. 


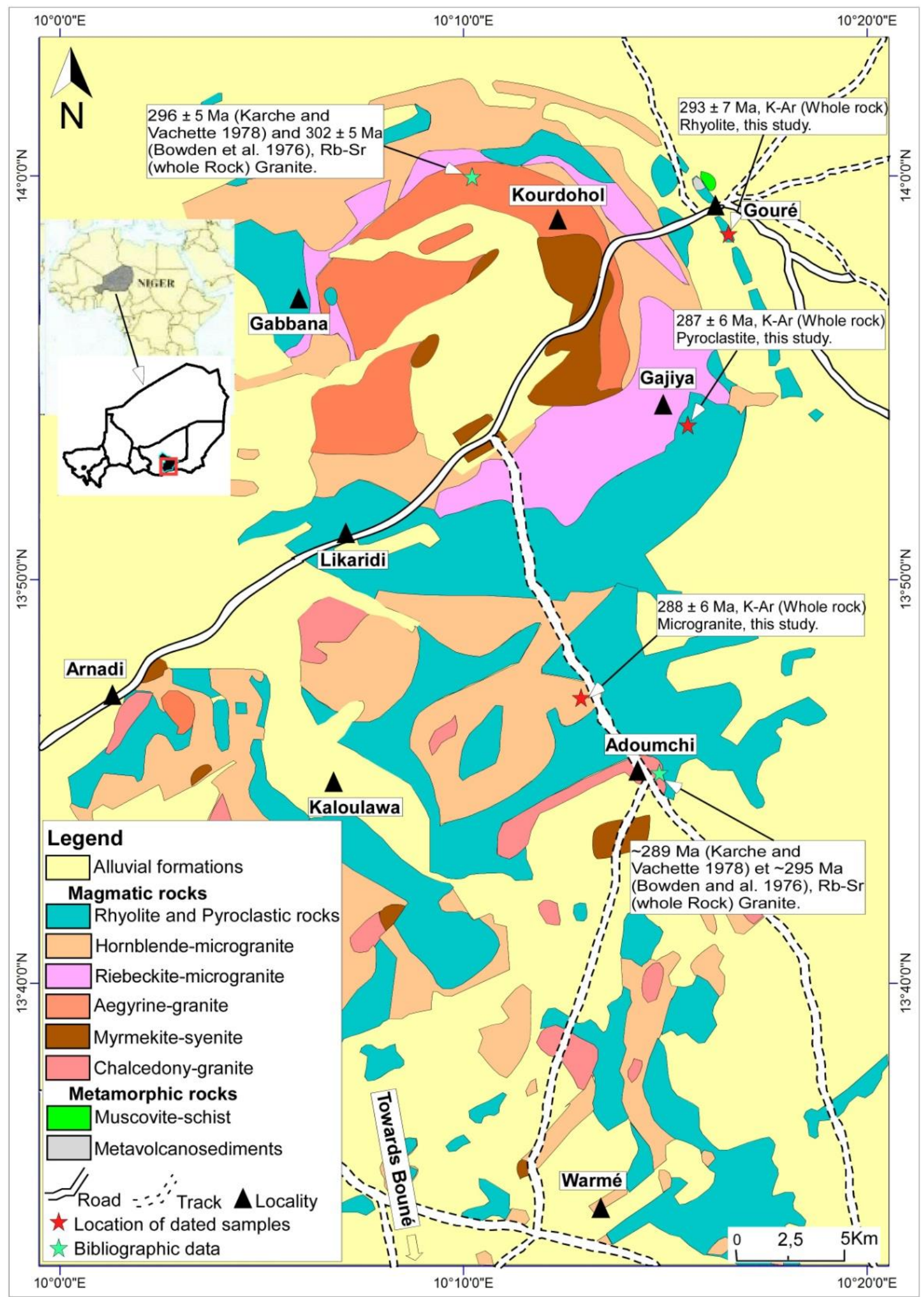

Fig. 3. Geological map of the Mounio province (after [9], supplemented by field data) showing the location of the sampling points.

\section{Methodology}

\section{A. Choice of Method}

The province of Mounio is made up of acidic, alkaline to hyperalcaline, magmatic and metamorphic rocks. The K-Ar dating method is suitable for these types of rocks because they are rich in mobile elements such as potassium, including the radioactive isotope ${ }^{40} \mathrm{~K}$ which decays into ${ }^{40} \mathrm{Ar}$. The choice of this technique is one of the most suitable alternatives, given the difficulty in finding certain elements (such as zircon), in the thin sections of the Mounio zone, necessary for testing other dating methods (such as the U-Pb 
method). The K-Ar method gives excellent results on igneous rocks [37], given the speed of magmatic intrusions thus favoring the closure of the system [38]. For metamorphic rocks, this technique provides relatively good results compared to other methods such as $\mathrm{U}-\mathrm{Pb}$ where the age of zircons is less precise, due to the loss of the $\mathrm{Pb}$ elements and the presence of very small inherited components [39].

\section{B. Analytical Technique}

Three samples, noted $\mathrm{GMS}_{23}$ (microgranite), GMS 49 (rhyolite), and $\mathrm{GMS}_{70}$ (pyroclastic rock) (location fig. 3) were submitted for total rock K-Ar geochronological analysis at ACTLabs laboratory of Canada. The samples were first assayed by X-rays (XRF) fluorescence which is an analytical technique that provides quantitative potassium (K) element data prior to the total rock K-Ar radiometric dating. Aliquots of each of the three samples were taken and weighed in an aluminum container. Appropriate weights are introduced into the extraction unit, heated to $\sim 100{ }^{\circ} \mathrm{C}$ for 2 days in order to remove surface gases from the samples. Argon is extracted from the samples in a boiler at a temperature of $1700^{\circ} \mathrm{C}$. The determination of the content of radiogenic argon was performed twice using the MI-1201 IG mass-spectrometer by isotope dilution method with ${ }^{38} \mathrm{Ar}$ as a peak, which is introduced to the sample system before each extraction. The extracted gases were cleaned up in two purification system. Then pure Ar is introduced into the custom-built magnetic sector of the mass spectrometer (Reinolds type). It should be noted that the test was performed twice on each sample to ensure the reliability of the results. Two globally accepted levels (P-207 Muscovite and 1/65 "Asia" rhyolite matrix) were measured for ${ }^{38} \mathrm{Ar}$ tip calibration. For age calculations, international constant values were used as follows: $\lambda_{\mathrm{K}}=0.581 \times 10^{-10} \mathrm{y}^{-1}$, $\lambda_{\beta^{-}}=4.962 \times 10^{-10} \mathrm{y}^{-1},{ }^{40} \mathrm{~K}=0.01167$ (At.\%). The certainty of the ages calculated fall within $1 \sigma$ error.

\section{RESULTS AND DISCUSSION}

\section{A. Data analysis and Interpretation}

Geochronological investigations in general, require knowledge of the geological context of the study area and a petrographic study of the rocks to be dated. Previous works have shown that the province of Mounio is dominated by an anorogenic alkaline complex except for a few metasediments' hints. The data presented relate to the results of petrographic and radiometric analysis of the formations. The latter are composed of Gouré rhyolites, Adoumchi microgranites and pyroclastic rocks of Gajiya (Fig. 3).

\section{1) Gouré Rhyolites}

The Gouré rhyolites outcrop in the form of small hills encircling the Gouré city (fig. 3). They are pinkish to greyish in color, marked by a microlitic porphyritic texture (Fig. 4a). The mineralogical composition is characterized by millimetric to centimetric crystals of automorphic quartz, alkaline feldspars, pyroxenes, biotites, embedded in a quartzofeldspathic mesostasis (Fig. 4a, 4c, 4d). The latter is dotted with reddish spatches of iron oxides (Fig. 4a), in which phenocrysts of pyroxenes and plagioclases are embedded (Fig. 4a). These more or less porphyritic rhyolites (Fig. 4c, 4d), with abundant mesostasis, sometimes present magmatic bedding (orientation of plagioclase phenocrysts). At the outcrop scale, the Gouré rhyolites are locally affected by a tight fracture cleavage $\mathrm{N} 140^{\circ}$ to $\mathrm{N} 160^{\circ}$ trending (Fig. $4 b$.
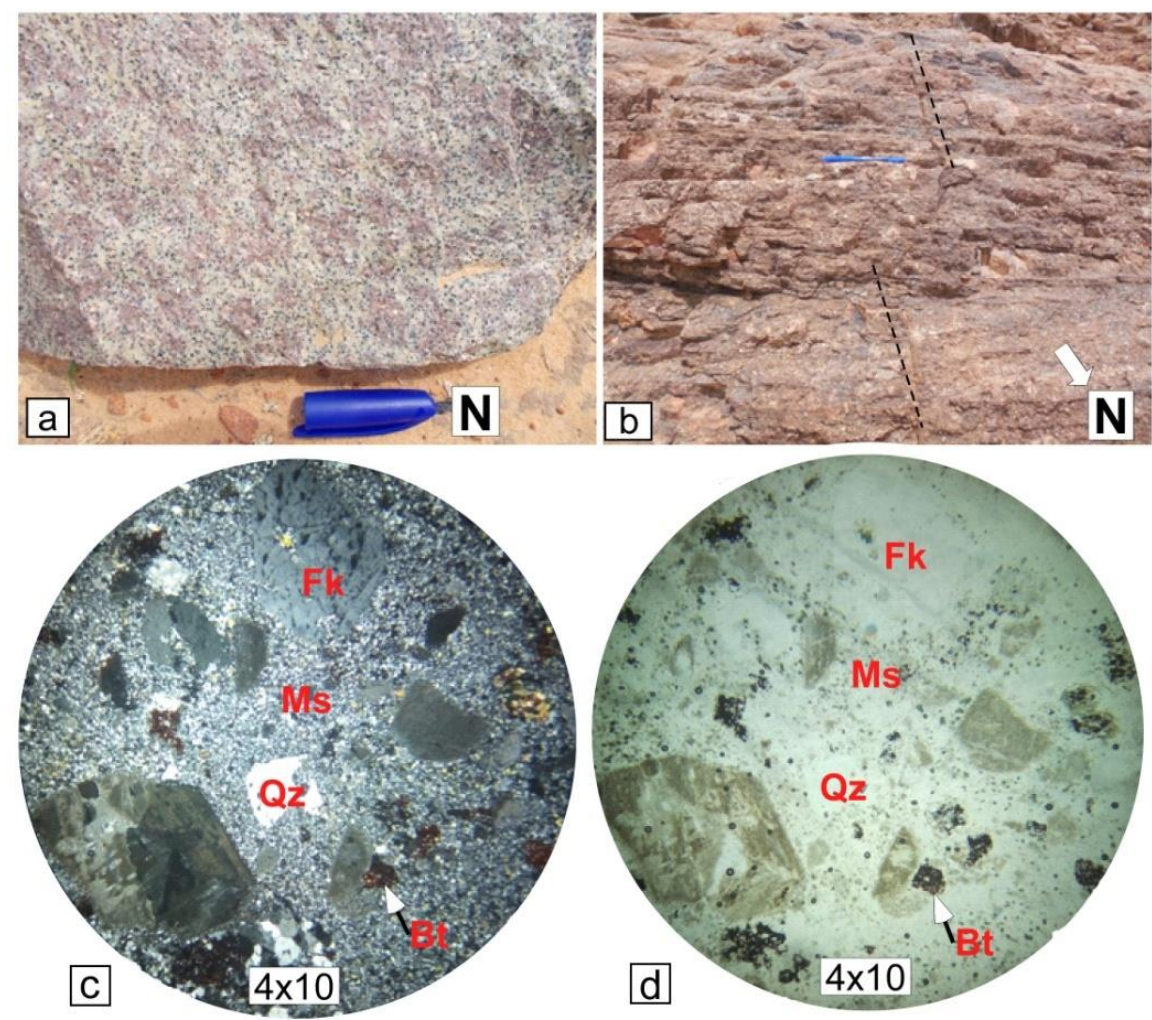

Fig. 4. Gouré Rhyolites. Outcrop view showing microlitic texture (a) and tight fracture cleavage N140 ${ }^{\circ}$ to N $160^{\circ}$ trending (b). Microphotography with a polarizing microscope in polarized and analyzed light (c) and non-analyzed polarized light (d). [Qz: Quartz. Fk: Potassic feldspars. Ms: Mesostasis. Bt: Biotite]. 
Radiometric dating of the Gouré rhyolite sample gave an age of $293 \pm 7 \mathrm{Ma}\left(\mathrm{GMS}_{49}\right.$, Table I, II), which would be that of the setting up of the rhyolite. Petrographic analysis shows that this rock is characterized by the lack of deformed or oriented minerals, which implies that there was neither intercrystalline ductile deformation nor metamorphic deformation (Fig. 4c, 4d). The tight fracture cleavage could then be contemporaneous with the cooling period of the rhyolitic lava.

\section{2) Adoumchi Microgranites}

The Adoumchi microgranites also exhibit a fracture cleavage, indicating an average direction of $\mathrm{N} 00^{\circ}$, giving the rock a prismatic flow at the outcrop (Fig. 5a). Their pinkish facies with micrograined texture a retypical of hypovolcanic rocks. Adoumchi microgranites consist of quartz, orthose, muscovite, biotite, plagioclase, hornblende, and a cryptocrystalline mesostasis (Fig. 5b, 5c, 5d). These minerals don't show any intercrystalline deformation (Fig. $5 \mathrm{~b}, 5 \mathrm{c}, 5 \mathrm{~d})$.

Total rock dating, by the K-Ar method, of these microgranites gives an age of $288 \pm 6 \mathrm{Ma}\left(\mathrm{GMS}_{23}\right.$, Table I, II). Here too, the absence of deformed or oriented minerals implies that neither intracrystalline ductile deformation nor metamorphic deformation occurred (Fig. 5b, 5c, 5d). The
$\mathrm{N} 00^{\circ}$ fracture cleavage observed would be contemporaneous with the magma cooling period.

\section{3) Pyroclastic rocks of Gajiya}

These are rocks with rhyolitic tuffaceous facies (Fig. 6a), rich in potassic feldspars (Fig. 6a, 6b, 6c, 6d). These rocks are characterized by automorphic K-feldspar porphyroclasts, automorphic smoky quartz and quartzofeldspathic cryptocrystalline mesostasis (Fig. 6c, 6d). The outcrop is characterized by a magmatic bedding oriented mainly $\mathrm{N} 10^{\circ}$ $\mathrm{N} 20^{\circ}$. The Gajiya pyroclastic rocks are affected by a variety of microfolds, most often anisopachous, reflecting a high ductility of the magmatic material during the microfolding (Fig. 6a). Subsequently, this rock was affected by several generations of fracture cleavage, oriented $\mathrm{N} 10^{\circ}-\mathrm{N} 30^{\circ}, \mathrm{N} 60^{\circ}-$ $\mathrm{N} 80^{\circ}$ and $\mathrm{N} 100^{\circ}-\mathrm{N} 125^{\circ}$ (Fig. 6b). The description of the thin sections under a polarizing microscope shows that the minerals are not deformed. These pyroclastic rocks have therefore not undergone metamorphic deformation. The deformation structures observed at the outcrop (microfolds, magmatic bedding) would therefore be deformation linked to the conditions of the setting up of the magma.

Radiometric dating by the K-Ar method on a total rock gave an age of $287 \pm 6 \mathrm{Ma}\left(\mathrm{GMS}_{70}\right.$, Table I, II), which would be that of the establishment of the magmatic material and deformations associated with it.

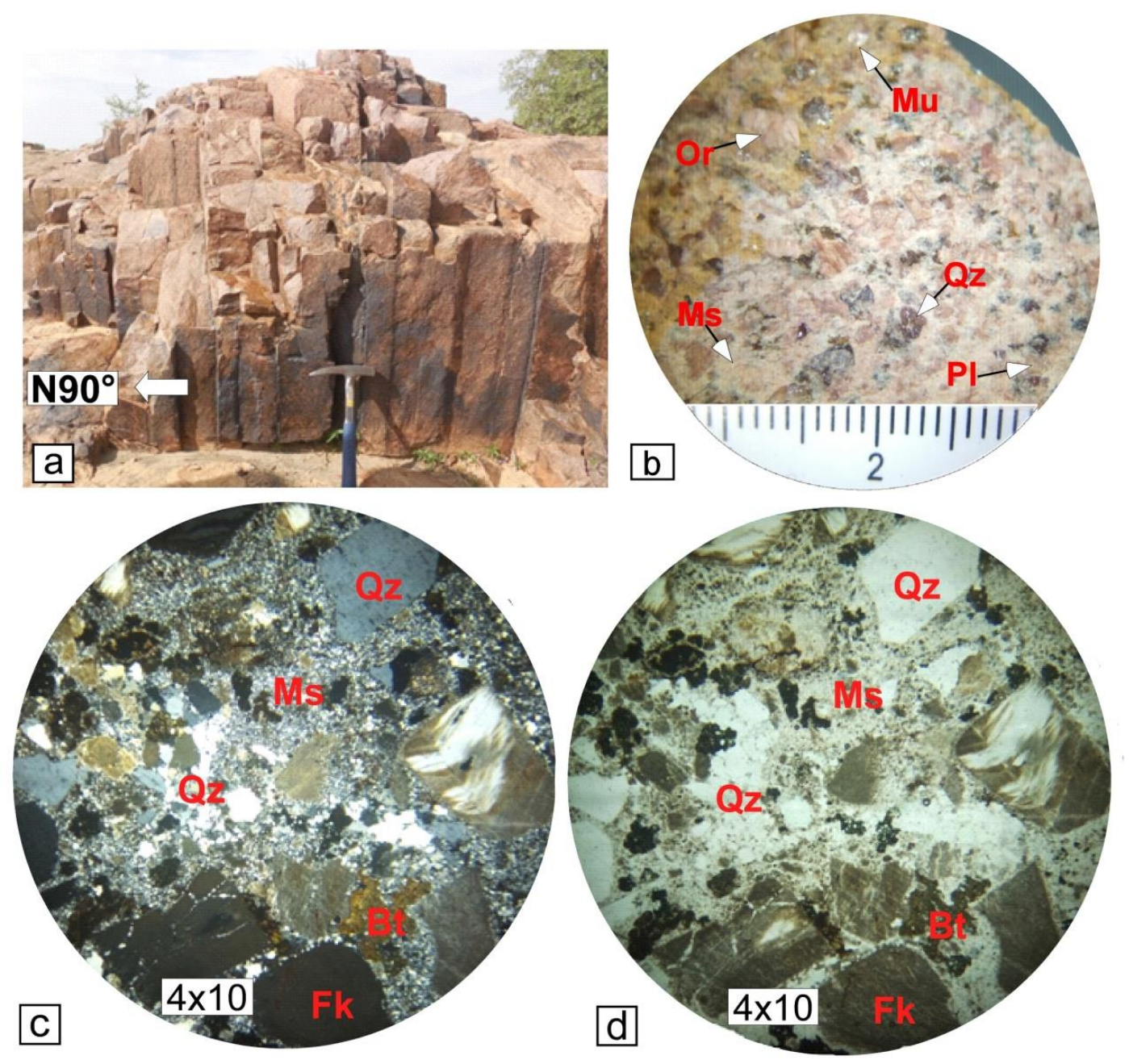

Fig. 5. Adoumchi Microgranites. Outcrop view showing an $N 00^{\circ}$ fracture cleavage and a prismatic flow (a). Photography with the binocular magnifying glass (b). Microphotography with a polarizing microscope with polarized and analyzed light (c) and unanalyzed polarized light (d). [Qz: Quartz. Or: Orthose. Mu: Muscovite. Pl: Plagioclase. Ms: Mesostasis, Bt: Biotite]. 

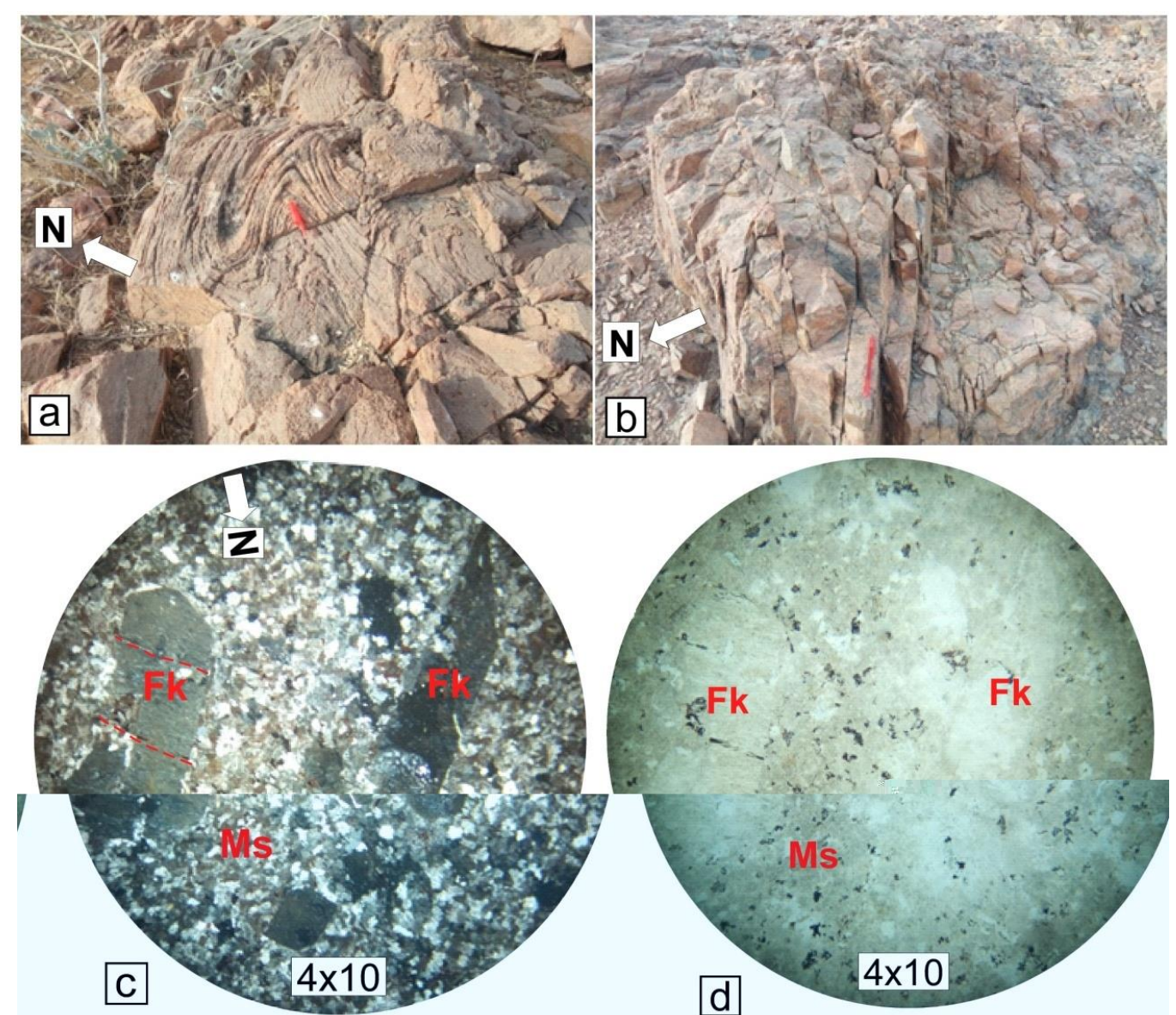

Fig. 6. Gajiya pyroclastic rocks. Outcrop view showing a folding deformation, intersected by $\mathrm{N} 100^{\circ}-125^{\circ}$ trending schistosity (a and b). Microphotography with a polarizing microscope in polarized and analyzed light (c) and unanalyzed polarized light (d). [Fk: Potassic feldspars. Ms: Mesostasis].

TABLE I: THE RESULT OF THE K-AR GEOCHRONOLOGY TEST

\begin{tabular}{cccccc}
\hline $\begin{array}{c}\text { Sample's } \\
\text { ID }\end{array}$ & $\begin{array}{c}\mathrm{K}, \\
\%\end{array}$ & $\begin{array}{c}{ }^{40} \mathrm{Ar} \mathrm{rad}, \\
(\mathrm{ng} / \mathrm{g})\end{array}$ & $\begin{array}{c}{ }^{40} \mathrm{Ar} \text { atm } \\
(\%)\end{array}$ & $\begin{array}{c}\text { Age } \\
(\mathrm{Ma})\end{array}$ & $\begin{array}{c}\text { Erreur } \\
1 \sigma\end{array}$ \\
\hline $\mathrm{GMS}_{23}$ & 3.72 & $80.62 \pm 0.27$ & 9.7 & 288 & 6 \\
$\mathrm{GMS}_{49}$ & 4.00 & $88.30 \pm 0.3$ & 13.5 & 293 & 7 \\
$\mathrm{GMS}_{70}$ & 5.26 & $113.60 \pm 0.4$ & 8.5 & 287 & 6 \\
\hline
\end{tabular}

\section{B. Discussion on the Obtained Ages}

Radiometric data obtained by the K-Ar method on total rock samples from the Mounio Province, yield lower Permian ages (293 \pm 7 to $287 \pm 6 \mathrm{Ma})$ [40]. These results are relatively younger than those resulting from the previous works of [6] and [4] who respectively obtained, by the Rb$\mathrm{Sr}$ method on total rock, ages ranging from $305 \pm 5$ to $\sim 295 \mathrm{Ma}$ and from $296 \pm 5$ to $\sim 289 \mathrm{Ma}$ from the same field (Table II).

Rhyolites and microgranites from Mounio showed respectively ages of $293 \pm 7 \mathrm{Ma}$ and $288 \pm 6 \mathrm{Ma}$. Their macroscopic and microscopic petrographic aspects (Fig. 4, 5) are those of the igneous rocks. The K-Ar method applied to alkaline igneous rocks provides good results [37]. These ages would correspond to the period of successive setting up of the alkaline complexes of the "Younger Granites" Province of Niger-Nigeria [1], [2], [4], [6]. Thus, the fracture cleavage observed in the rhyolites of Goure $\left(\mathrm{N} 140^{\circ}\right.$ $\left.\mathrm{N} 160^{\circ}\right)$ and in the microgranites of Adoumchi $\left(\mathrm{N} 00^{\circ}\right.$ on average) would rather be contemporaneous with the cooling period of the magma.
As for the pyroclastic rocks of Mounio, they clearly show ductile deformation structures (Fig. 6a). However, the microscopic study shows that this deformation is not recorded by the minerals, except for the fractures consistent with the $\mathrm{N} 100^{\circ}-\mathrm{N} 125^{\circ}$ fracture cleavage which affected the potassium feldspar porphyroclasts. This rock would therefore be affected by deformation structures linked to the conditions of setting up of the magma. It would then be synmagmatic deformation structures.

The results of this study correspond to a distinctly Permian period [40] unlike the carboniferous age attributed to the "Younger Granites" of Mounio by [6] and [4]. These new radiometric data also contrast the Jurassic and DevonoCarboniferous periods proposed respectively by [9] and [10].

In general, the available geochronological data in the study area which are: (i) from $293 \pm 7$ to $287 \pm 6 \mathrm{Ma}$ (K-Ar on total rock) resulting from this study, (ii) from $296 \pm 5$ to $289 \mathrm{Ma}$ ( $\mathrm{Rb}-\mathrm{Sr}$ on total rock) from [4] and, (iii) from $305 \pm 5$ to $\sim 295 \mathrm{Ma}$ (Rb-Sr on total rock) from [6] (Table II), show increasingly younger ages from the North to the South of Mounio, relatively to the type of method used (Fig. 3). This observation is in agreement with the conclusions of [6] and [4] on the migratory character of the ages of the establishment of the "Young Granites" of Niger-Nigeria (from the Ordovician in Aïr, to the Cretaceous in the Jos Plateau, in Nigeria). This means that the magmatism of the Mounio province would have started in the extreme North with the setting up of the Gouré annular structure before gradually migrating Southwards, towards Nigeria. 
TABLE II: GPS LOCATION AND RADIOMETRIC AGES OF THE BASEMENT SAMPLES OBTAINED By K-AR DATING (DURING THIS STUDY) AND RB-SR DATING [4], [6]

\begin{tabular}{|c|c|c|c|c|c|}
\hline \multirow[t]{2}{*}{ Samples analyzed } & \multicolumn{2}{|c|}{$\begin{array}{l}\text { Geographical coordonates } \\
\text { in degree-minute-second }\end{array}$} & \multicolumn{2}{|c|}{ Radiometric ages } & \multirow{2}{*}{$\begin{array}{l}\text { Method/material } \\
\text { dated }\end{array}$} \\
\hline & Longitude & Latitude & Measured ages & Recalculed ages & \\
\hline Adoumchi Microgranite & $\mathrm{E} 10^{\circ} 13^{\prime} 14^{\prime \prime}$ & $\mathrm{N} 13^{\circ} 46^{\prime} 47^{\prime \prime}$ & $288 \pm 6 \mathrm{Ma}$ (this study) & & K-Ar on Whole rock \\
\hline Gouré Rhyolite & $\mathrm{E} 10^{\circ} 16^{\prime} 38^{\prime \prime}$ & 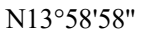 & $293 \pm 7 \mathrm{Ma}$ (this study) & & K-Ar on Whole rock \\
\hline $\begin{array}{c}\text { Pyroclastic rocks of } \\
\text { Gajiya }\end{array}$ & $\mathrm{E} 10^{\circ} 15^{\prime} 22^{\prime \prime}$ & N135'5" & $287 \pm 6 \mathrm{Ma}$ (this study) & & K-Ar on Whole rock \\
\hline Granite of Kourdohol & $\mathrm{E} 10^{\circ} 10^{\prime} 00^{\prime \prime}$ & $\mathrm{N} 14^{\circ} 00^{\prime} 00^{\prime \prime}$ & $302 \pm 5 \mathrm{Ma}$ (Bowden, 1976) & $\begin{array}{c}296 \pm 5 \text { Ma (Karche } \\
\& \text { Vachette, 1978) }\end{array}$ & $\mathrm{Rb}-\mathrm{Sr}$ on Whole rock \\
\hline Granite of Adoumchi & E10¹4'53" & N13ㄴ5'06" & $295 \mathrm{Ma}$ (Bowden, 1976) & $\begin{array}{c}\text { 289 Ma (Karche \& } \\
\text { Vachette, 1978) }\end{array}$ & $\mathrm{Rb}-\mathrm{Sr}$ on Whole rock \\
\hline
\end{tabular}

\section{CONCLUSION}

Geochronological data obtained by the K-Ar method on the Gouré massif, give Permian ages ranging from $293 \pm 7$ to $287 \pm 6 \mathrm{Ma}$, unlike the Carboniferous ages classically assigned to the Mounio "ring complex". These ages correspond to the period of setting up of the Mounio "Younger Granites". The deformation structures observed on the volcanic, hypovolcanic and plutonic terrains of Mounio alkaline annular complex, would then result from tectono-magmatic events, Permian in age. From a regional point of view, these results confirm the migratory ages of the Niger-Nigeria "Younger Granites" provinces and the establishment of the granite complex of the Mounio province during the Hercynian period.

\section{ACKNOWLEDGMENT}

This work was received logistical support from Abdou Moumouni University (UAM) of Niamey, Niger. The authors are much grateful to UAM.

\section{CONFLICT OF INTEREST}

Authors declare that they do not have any conflict of interest.

\section{REFERENCES}

[1] Moreau C., Demaiffe D., Bellion Y., Boullier A.-M. A tectonic model for the location of Palaeozoic ring complexes in Aïr (Niger, West Africa). Tectonophysics, 1994; 234.129-146. doi: 10.1016/00401951(94)90208-9.

[2] Vail J. R. Ring complexes and related rocks in Africa. Journal of African Earth Sciences, 1989; 8(1):19-40. doi: 10.1016/S08995362(89)80006-5.

[3] Bowden, P., Black, R., Martin, I F., Ike, I. C., Kinnaird, J. A. and Batchelor, R.A. Niger-Nigeria alkaline ring-complexes: a classical example of African Phanerozoic anorogenic told-plate magmatism. In: Alkaline Igneous Rocks. J. G. Fltton and B. J. G. Upton Eds, Geol. Soc. Spec. Publ.1987;30:357-379. doi: 10.1002/gj.3350220622.

[4] Karche J. P. et Vachette M. Age et migration de l'activité magmatique dans les complexes paléozoïques du Niger, conséquences. Bull. Soc. Géol. Fr., 1978; 20:941-953.

[5] Karche J. P. et Vachette M. Migration des complexes subvolcaniques à structure annulaire du Niger. Conséquences. C. R. Ac. Sci., Paris, t. 281. P. 2033-3036. 1976.

[6] Bowden P., Van Breemen D., Hutchinson J. et Turner D. C. Paleozoic and Mesozoic ages trends for some ring complexes in Niger and Nigeria. Nature, 1976;259, 5541: 297-299.

[7] Breemen O. Van, Hutchinson J. et Bowden P. Age and origin of the Nigerian mesozoic granites: a Rb-Sr isotopic study, contrib. Mineral. Petrol., 1975;50:157-172. doi: 10.1007/BF00371037.
[8] Breemen, O. Van and Bowden, P. Sequential age trends for some Nigerian Mesozoic granites. Nature, 1973;242:9-11. doi: 10.1038/physci242009a0.

[9] Mignon R. Etude géologique et prospection du Damagaram-Mounio et du Sud-Maradi, Rapport BRGM, 68 p. 1970.

[10] PRDSM. Notice de la carte geologique du damagaram-mounio (Echelles 1/100 000 et 1/200 000), Assistance technique dans le

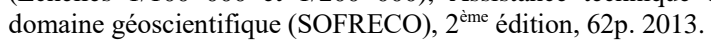

[11] Caby R. Terrane assembly and géodynamic evolution of centralwestern Hoggar, a 730 Macratonic black in the panafrican belt of the northern African Continent. Precambrien research, 2003;36:335-344. doi: 10.1016/j.jafrearsci.2003.05.003.

[12] Abdelsalam M.G., Liégeois J.P., Stern R.J. The Saharan Metacraton. Journal of African Earth Sciences, 2002; 34(3-4):119-136. doi: 10.1016/S0899-5362(02)00013-1.

[13] Ferré E., Gleizes G. and Caby R. Obliquely convergent tectonics and granite emplacement in the Trans-Saharan belt of Eastern Nigeria : a synthesis. Precambrian research, 2002;114:199-219 p. doi: 10.1016/S0301-9268(01)00226-1.

[14] Black R., L. Latouche, J-P. Liégeois, R. Caby, J. M. Bertrand. PanAfrican displaced terranes in the Tuareg shield (central Sahara). Geology, 1994;22:641-644.

[15] Koner A. and Stern R.J. Pan African orogeny. In: Selley, R.C., Cocks, L.R.M., Plimer, R.I. (Eds.), Encycl. Geol. 1, 2005:1-12.

[16] Ferré E., Deleris J., Bouchez J. L., Lar A.U., and Peucat J. J. The PanAfrican reactivation of Eburnean and Archaean provinces in Nigeria: structural and isotopic data. J. Geol. Soc. London, 1996;153:719-728. doi: 10.1144/gsjgs.153.5.0719.

[17] Castaing C., Triboulet C., Feybesse J. L. et Chèvremont P. Tectonometamorphic evolution of Ghana, Togo and Benin in the light of the Pan-African/Brasiliano orogeny. Tectonophysics, 1993; 218:323-342. doi.10.1016/0040-1951(93)90322-B.

[18] Ajibade, A. C. et Wright, J. B. The Togo-Benin-Nigeria Shield: evidence of crustal aggregation in the Pan-African belt. Tectonophysics, 1989; 165: 125-129. doi: 10.1016/00401951(89)90041-3.

[19] Caby R. Precambrian terranes of Benin- Nigeria and Northeast Brazil and the late Proterozoic south Atlantic fit. Geol. Soc. Am. Special Pap., 1989;230:145-158.

[20] Breemen O. Van, Pidgeon, R. T. et Bowden, P. Age and isotopic studies of some Pan-African granites from north-central Nigeria. Precambrian Res., 1977;4:307-319. doi: 10.1016/03019268(77)90001-8.

[21] Black R., Liégeois J. P., Navez J. \& Vialette Y. Terrains exotiques dans les zones internes de la chaîne panafricaine transsaharienne : les clefs fournies par l'Aïr sud-oriental (République du Niger), C.R. Acad. Sci. Paris. 1991.

[22] Ba H., Black R., Benziane B., Diombana D., Hascoet-Fender J., Bonin B., Fabre J., Et Liegeois J. P... La province des complexes annulaires alcalins sursaturés de l'adrar des Iforas, Mali. Journal of African Earth Sciences, 1985;3(1/2):pp. 123-142. doi: 10.1016/08995362(85)90031-4.

[23] Ngako V., Nionfang E., Tongwa Aka F., Affaton P., Metuk Nnange J. The North-South Paleozoic to Quaternary trend of alkaline magmatism from Niger-Nigeria to Cameroon: Complex interaction between hotspots and Precambrian faults. Journal of African Earth Sciences, 2006;45(3):241-256. doi:10.1016/j.jafrearsci.2006.03.003.

[24] Black, R., Lameyre, J. and Bonin, B. The structural setting of alkaline ring-complexes. J. Aft. Earth ScL, 1985;3:5-16.

[25] Ajakaiye D. E., Bowden P., Hall D. H., Verheijen P. J. T. Age migrations and aeromagnetic anomalies in anorogenic ring complexes from northern Nigeria. Conférence abstracts. Journal of African Earth Sciences, 1985;3(1/2):273-277. 
[26] PRDSM. Projet de géophysique aéroportée dans le secteur Sud Maradi, 2005, $55 \mathrm{p}$.

[27] Bruguier O., Dada S. and Lancelot J. R. Early Archaean component (>3.5 Ga) within a $3.05 \mathrm{Ga}$ orthogneiss from northern Nigeria; U-Pb zircon evidence, Earth and Planetary Science Letters, 1994;125(1-4): 89-103. doi: 10.1016/0012-821 x(94)90208-9.

[28] Liégeois J. P., Latouche L., Boughrara M., Navez J. and Guiraud M. 2003. The LATEA metacraton. (Central Hoggar, Tuareg shield, Algeria): behaviour of an old passive margin during the Pan-African orogeny. Journal of African Earth Sciences, 2003;37:161-190. doi:10.1016/j.jafrearsci.2003.05.004.

[29] Trompette R. Neoproterozoic ( 600 Ma) aggregation of Western Gondwana: a tentative scenario. Precambrian Research, 1997;82:101112.

[30] Villeneuve M. and Cornée J. J. Structure, evolution and palaeogeography of West African craton and bordering belts during the Neoproterozoic. - Prec. Res., 1994;69:307-326. doi:10.1016/03019268(94)90094-9.

[31] Stern R. J. Arc assembly and continental collision in the Neoproterozoic East African orogeny - implications for the consolidation of Gondwana, Annual Review of Earth and Planetary Sciences, 1994;22:319-351.

[32] Baraou I. S. \& Konaté M. Kinematic evolution of the Pan-African shear zones of South Maradi, Southern Niger. Global Journal of Earth and Environnemental Science, 2020a;5(4):101-116. doi: 10.31248/GJEES2020.087

[33] Baraou I. S. \& Konaté M. New radiometric data from the South Maradi Pan-African formations, southern Niger. J. Geol. Soc. London, Special Publications. 2020b. doi :10.1144/SP502-2019-151.

[34] Black R. et Morosoff. W. Rapport provisoire sur les youngers granites de la région de Zinder-Gouré. B.R.G.M. Dakar. 1960

[35] Black R. Note sur les complexes annulaires de Tchouni-Zarnouski et de Gouré, Bull. B.R.G.M. Fr., Nº1. 1963.

[36] Tidjani A.D. Erosion éolienne dans le Damagaram Est (Sud-Est du Niger): Paramétrisation, quantification et moyens de lutte. Thèse de doctorat de l'Université Catholique de Louvain. 2008

[37] Scott Sinnock, Robert G. Easterling. Empirically determined uncertainty in Potassium-Argon ages for Plio-Pleistocene basalts from crater flat, Nye County, Nevada. Sandia National Laboratories, Albuquerque, New Mexico 87185 and Livermore, California 94550 1983.

[38] Dodson M.H. Closure Temperature in Cooling Geochronological and Petrological Systems, in Contrib Mineral Petrol, volume 40, pages 259 à 274. 1973. doi: 10.1007/BF00373790.

[39] Müller W., Aerden D., Halliday A.N. Isotopic dating of strain fringe increments: duration and rates of deformation in shear zones, in Science, volume 288, pages 2195 à 2198. 2000.

[40] Cohen, K.M., Finney, S.C., Gibbard, P.L. \& Fan, J.-X. (2013; updated) The ICS International Chronostratigraphic Chart. Episodes 36:199-204. 2021.

URL:http://www.stratigraphy.org/ICSchart/ChronostratChart2021-

07.pdf. 